\title{
The Road from Massachusetts to Missouri: What Will It Take for Other States to Replicate Massachusetts Health Reform?
}

\author{
Sidney D. Watson, Timothy McBride, ${ }^{* *}$ Heather Bednarek, ${ }^{* * *}$ and \\ Muhammad Islam ***
}

In April 2006, the Massachusetts Legislature passed Chapter 58 of the Acts of 2006, An Act Providing Access to Affordable, Quality, Accountable Health Care, sweeping health reform legislation designed to achieve nearly universal health insurance coverage. ${ }^{1}$ While Massachusetts is not the first state in recent years to enact legislation intended to achieve near-universal coverage, its efforts have attracted the most national attention and the most notice from other states interested in duplicating the Massachusetts Model.

Fortuitous political and budgetary circumstances converged in Massachusetts to move reform forward. First, stakeholders and elected officials worked together over a number of years to develop a political consensus that the goal of health care reform should be universal coverage - or at least near universal coverage — and that anything short

* Professor of Law, Saint Louis University School of Law Center for Health Law Studies.

** Professor, Department of Health Management and Policy, Saint Louis University School of Public Health.

*** Assistant Professor, Department of Economics, Saint Louis University John Cook School of Business.

**** Professor, Department of Economics, Saint Louis University John Cook School of Business.

Our thanks to the other members of the Saint Louis University Health Policy team who collaborated with us on this project: Dan Gentry, Michael Counte and Nicolas Terry. We also wish to thank the other members of the Saint Louis University Health Policy Legislative Analysis Team for their suggestions and guidance of the research that serves as the basis for this article. In particular, Kathy Gillespie, Rick Kurz and Kanak Gautum provided comments and suggestions. We also appreciate the excellent research contributed by Research Assistants Rebecca Frigy, Sarah Kaufman, Tameka Stigers, Emily Simpson, and Tanchica Terry. This work was supported by a grant from the Missouri Foundation for Health. Our thanks to Thomas McAuliffe and Leslie Reed for their ongoing support and encouragement.

1. An Act Providing Access to Affordable, Quality, Accountable Health Care, ch. 58, 2006 Mass. Acts (forthcoming), available at http://www.mass.gov/legis/laws/seslas069/51060058.htm [hereinafter An Act Providing Access to Health Care] 
of that goal would have undesirable human, financial, economic and political costs. ${ }^{2}$ Moreover, the Commonwealth already allocated over $\$ 1$ billion a year to cover the costs of care for the uninsured, money that could be partially or fully shifted to help subsidize health insurance coverage for low income families in a system designed to create near universal coverage. ${ }^{3}$ Finally, the threatened loss of $\$ 385$ million in federal Medicaid matching funds on July 1, 2006, helped propel the Commonwealth to quickly enact reform legislation quickly. ${ }^{4}$

From this perfect storm of political events emerged the Massachusetts Model: an incremental health reform package designed to move the state to near-universal health insurance without disrupting existing coverage. The Massachusetts Model builds on the existing private health insurance system, both employer-sponsored and individual, leverages federal Medicaid funds to help support Medicaid coverage and private insurance subsidies for lower income Massachusans, and does not require substantial new state revenue funding. With these design features, it is not surprising that the Massachusetts Model has attracted widespread interest.

However, before attempting to replicate the Massachusetts Model, state lawmakers must explore two basic questions. First, what are the legal frameworks that support the Massachusetts Model, and how might other states adapt these structures? Descriptions of the legislation describe a dizzying array of newly authorized regulatory entities that administer various elements of the reform plan. What are the basic legal and regulatory structures that underlie the Massachusetts Model and how can other states duplicate them?

Second, what is the Massachusetts Model likely to cost in other states? Since no other state has a \$1 billion Uncompensated Care Pool that can be shifted from charity care to health insurance coverage, do other states have funds that can be shifted from covering uncompensated care to funding health insurance expansions? In short, can other states afford to replicate the Massachusetts Model?

This article examines both questions using Missouri as a prototype. This work is the outgrowth of an interdisciplinary project to analyze the feasibility — both legal and financial—of using the Massachusetts Model

2. See John McDonough et al., The Third Wave of Massachusetts Health Care Access Reform, HEALTH AFF., WEB EXClusives, Nov.-Dec. 2006, at w420, w429.

3. See generally John Holahan \& Linda Blumberg, Massachusetts Health Care Reform: A Look at the Issues, HEALTH AFF. WEB ExCLUSIVES, Nov.-Dec. 2006, at W432, 432.

4. McDonough et al., supra note 2 , at W429. 
to create near universal access to health insurance in Missouri. ${ }^{5}$ That research was intended to prompt a policy and political dialogue within the state of Missouri.

Missouri is an ideal focus for this work because of the lessons it offers to other states: Missouri is a "bell weather" state that predicts policy and political trends across the country. As a health care trendsetter, Missouri was a leader in expanding health insurance for children. In 1998, it was one of the first states to raise children's eligibility for the State Children's Health Insurance Program (SCHIP) and Medicaid to $300 \%$ of the federal poverty level (FPL). ${ }^{6}$ In 2005, Missouri was also a leader in Medicaid retrenchment, cutting over 100,000 people from Medicaid to trim a budget buffeted by an economic downturn. ${ }^{7}$ Today, Missouri is at the forefront of debates about using public-private partnerships to restructure Medicaid. ${ }^{8}$ What happensand what can happen-in Missouri offers important lessons about what is possible and what is likely in other states.

Part I of this article describes who has health insurance and who does not to help policy-makers gain a better understanding of who the uninsured are and the kinds of health insurance expansion strategies that states need to consider. Part II explains the legal frameworks that underlie the Massachusetts Model and the legal structures other states need to replicate it. Part III calculates the costs-both positive and negative-of instituting a Massachusetts Model in Missouri. It also explores how states, like Missouri, that are reluctant to impose state individual and corporate income taxes can finance the state's costs through more targeted taxes on medical services, insurance premiums, and tobacco products.

5. This research was funded by the Missouri Foundation for Health, a not for profit foundation founded in 2000 whose mission is to empower the people of the communities they serve to achieve equal access to quality health services that promote prevention and encourage healthy behaviors.

6. See Timothy McBride et al., The Missouri Health LandSCAPE: How does IT COMPARE TO MASSACHUSETTS? 14 (2006), http://www.mffh.org/MissouriHealthCareLandscape.pdf (stating that, in 2001, Missouri implemented SCHIP coverage for families with incomes up to $300 \%$ of the FPL); Letter from Kathryn G. Allen, Director, Health Care-Medicaid and Private Health Insurance Issues, U.S. General Accounting Office, to Christopher S. Bond, U.S. Senator (July 25, 2001), http://www.gao.gov/new.items/d01993r.pdf (showing that only four states, as of 2001, allowed SCHIP enrollment when a family's income was $300 \%$ or more of the FPL).

7. Donna Cohen Ross \& LaURa Cox, In a Time of Growing NeEd: State Choices Influence Health Coverage ACCESS for ChILDREN AND Families 9 (2005), http://www. kff.org/medicaid/upload/In-a-Time-of-Growing-Need-State-Choices-Influence-HealthCoverage-

Access-for-Children-and-Families-Report.pdf. Tennessee was the leader, cutting over 200,000 adults. Id.

8. See generally MEDICAID REFORM COMMISSION REPORT 35-36, http://www.senate.mo.gov/ medicaidreform/MedicaidReformCommFinal-122205.pdf [hereinafter MEDICAID REPORT] (discussing transformation toward a public-private system). 
Our study concludes that while the costs of implementing the Massachusetts Model in a state like Missouri are substantial they are not prohibitive in terms of the state dollars required. Federal Medicaid matching funds pay for one-half to two-thirds of the cost of health insurance expansions to cover low income residents. While no state has a charity care pool as large as Massachusetts, Missouri spends over $\$ 600$ million a year to fund uncompensated care, ${ }^{9}$ money that could be shifted to subsidize health insurance coverage. Although Missouri-like every state other than Massachusetts-would need new state revenue to fund a Massachusetts Model, the amounts required are relatively modest when compared to overall state revenues. ${ }^{10}$ Ultimately, we conclude that the Massachusetts Model offers a good investment for Missouri and other states.

\section{THE HEALTH INSURANCE LANDSCAPE: UNDERSTANDING WHO NEEDS INSURANCE}

In 2004, the most recent year for which data is available, health insurance coverage in Massachusetts and Missouri looked strikingly similar and better than the national average. Nationwide, almost $18 \%$ of Americans-45.5 million people-were uninsured at some point during the year. ${ }^{11}$ However, both Massachusetts and Missouri had relatively low rates of uninsurance- $12.7 \%$ in Massachusetts and $13.6 \%$ in Missouri. ${ }^{12}$ In both states, this relatively rosy picture was the result of strong employer-sponsored insurance coverage: $67.7 \%$ in Massachusetts and $65.1 \%$ in Missouri compared to $61 \%$ nationally. ${ }^{13}$ Both states also had robust individual insurance markets covering $4.8 \%$ of residents in Massachusetts and $5.4 \%$ in Missouri compared to $2.3 \%$ nationally. ${ }^{14}$ Both states also had sturdy Medicaid programs, with enrollment rates that mimicked the national average: $13.5 \%$ in Massachusetts and $13.8 \%$ in Missouri compared to $13.4 \%$, nationally. ${ }^{15}$

9. RANDALl R. BOVBJerg ET Al., THE COST OF CARE For Missouri's UNinSURED (2006), http://www.mffh.org/CoverMoDataBook2.pdf.

10. See infra text accompanying note 124 .

11. MCBRIDE ET AL., supra note 6, at 2.

12. Id.

13. Id.

14. Id.

15. Id. In 2005, the Missouri legislature enacted dramatic Medicaid cuts, eliminating coverage for over 100,000 people. Ross \& CoX, supra note 7, at 9. Between January 2005 and January 2007, the number of eligible Medicaid enrollees fell from 1,001,999 to 825,378. Missouri Department of Social Services, Caseload Counter Historical Data (2007), http://www.dss.mo.gov/mis/clcounter/ history.htm. Although data is not yet available showing how these cuts affected overall insurance 


\section{Figure 1. Health Insurance Coverage in Massachusetts and Missouri}
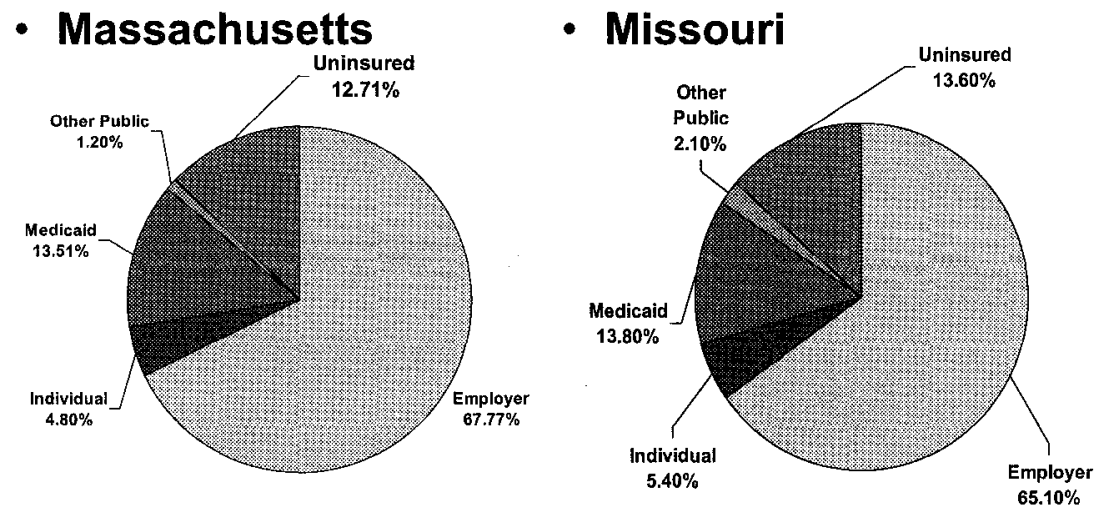

Source: Urban Institute \& Kaiser Commission on Medicaid and the Uninsured, CPS Annual Social and Economic Supplements (2005).

In both Massachusetts and Missouri-as across the U.S.- over $80 \%$ of the uninsured are workers and their dependents. ${ }^{16}$ While the country as a whole saw precipitous drops in employer-sponsored coverage from 2001-2004, Massachusetts still reported that $84 \%$ of the uninsured were workers or their dependents. ${ }^{17}$ In Missouri, the figure was $81 \%{ }^{18}$

rates in the state, most commentators believe that the cuts to parents' and children's eligibility increased uninsurance rates among these two groups because prior experience with Medicaid shows that these groups are unlikely to move from Medicaid into employer-sponsored private insurance coverage. Ross \& CoX, supra note 7, at 9. While the Missouri data presented in this section uses insurance statistics from 2004 that do not reflect these Medicaid cuts, estimates of the costs of implementing a Massachusetts Model in Missouri factor in the costs of covering these newly uninsured Missourians.

16. MCBRIDE ET AL., supra note 6, at 8 .

17. Id.

18. Id. Although Missourians, like other Americans have seen a substantial drop in employersponsored coverage between 2000 and 2004 because of the overall economic slump, Missouri's rate of employer sponsored coverage is still above the national average. See JOHN HOLAHAN \& ALLISON

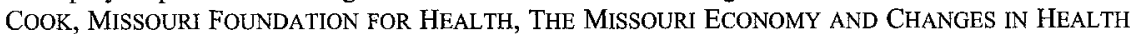
INSURANCE COVERAGE, 2000-2004, at 3 (2006) (listing Missouri's rate of employer-sponsored coverage as $64.2 \%$ ). 


\section{Figure 2. Uninsured Workers by Firm Size in Massachusetts and Missouri}

\section{- Massachusetts}

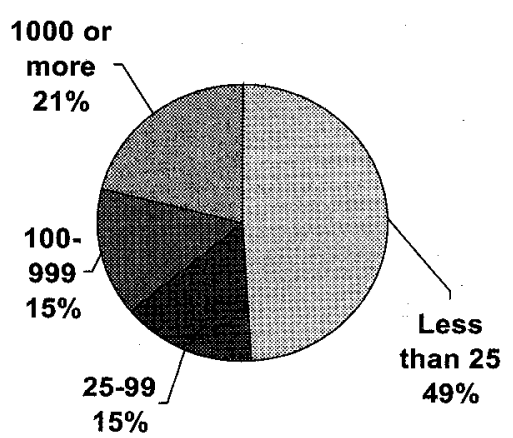

- Missouri

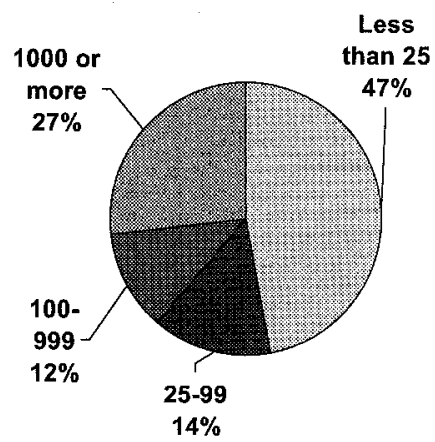

Source: Timothy McBride, et al., The Missouri Health Landscape, How Does it Compare to Massachusetts? (2006).

While over a quarter of uninsured workers are employed by very large businesses, most uninsured workers work for small firms. ${ }^{19}$ In Missouri, $61 \%$ of uninsured workers work for firms with fewer than 100 workers and almost half (47\%) work for very small firms with fewer than 25 workers. $^{20}$ One reason for high uninsurance rates among small firm workers is that smaller firms are less likely to offer employer sponsored coverage. In Massachusetts, $56.2 \%$ of employees who work for very small businesses are offered insurance, in Missouri the figure drops to only $41.2 \%{ }^{21}$ By comparison, over $90 \%$ of employees who work for firms with more than 50 employees are offered insurance. ${ }^{22}$

19. KAISER COMM'N ON KEY FACTS, UNINSURED WORKERS IN AMERICA 1 (2004), http:/www. kff.org/uninsured/upload/Uninsured-Workers-in-America.pdf. Nationally, $62 \%$ of uninsured workers are employed by firms with less than 100 people. Id. (see Figure 1). This figure does not include self-employed workers. Id.

20. MCBRIDE ET AL., supra note 6, at 11 .

21. Id. at 8 tbl.6. Smaller business is used here to denote employers who hire less than fifty employees. Id. Overall, only $53 \%$ of Missouri private firms offer their employees health insurance as compared to about $57 \%$ nationwide. Id. This is because, in recent years, employment in Missouri has shifted to smaller firms, which are less likely to offer insurance coverage. HOLAHAN \& COOK, supra note 18 , at 11 .

22. MCBRIDE ET AL., supra note 6, at 8 tbl.6. 
In terms of age, the group most likely to lack insurance is young adults, ages 19-34. In Massachusetts, 39\% of those in this age group did not have insurance. ${ }^{23}$ In Missouri, the figure is $44 \% .^{24}$ Young adults have unique issues in terms of health insurance coverage that explain this trend. Some are students who have aged out of their parents' dependent coverage and are not yet in the work force. Others are entering the work force for the first time in low wage or small firm jobs that do not offer health insurance. Still others have access to employer-sponsored insurance or individual insurance but decide the premium is too high in light of their relatively low risk of getting sick-a particular issue with healthy young men.

\section{Figure 3. The Uninsured by Age in Massachusetts and Missouri}

\section{- Massachusetts}

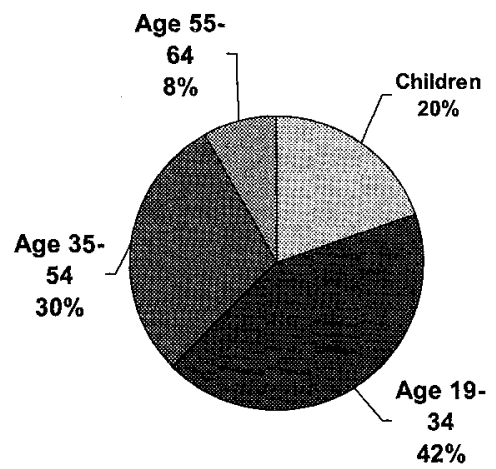

- Missouri

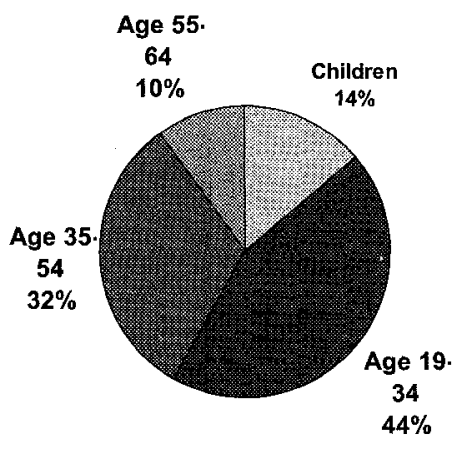

Source: Allison Cook, Health Insurance Coverage and the Uninsured in

Massachusetts, Blue Cross Blue Shield of Massachusetts Foundation (2005); Allison

Cook, Health Insurance Coverage in Missouri, Missouri Foundation for Health (2004).

Overwhelmingly, though, those who are uninsured are the working poor or near-poor: About half (49\%) of the uninsured in Missouri earn under $200 \%$ of the FPL, and fully $70 \%$ have incomes below $300 \%$ of the

23. Allison COOK, URBAN INSTit., HEALTH INSURANCE COVERAGE AND THE UNINSURED IN MASSACHUSETTS 18 fig.4 (2005), http://www.bcbsmafoundation.org/foundationroot/en_US/docu ments/uninsuredChartbook05.pdf.

24. HOLAHAN \& COOK, supra note 18 , at 14 app.B. In Missouri, about $60 \%$ of the increase in the uninsured between 2000 and 2004 was among adults between the ages of nineteen and thirtyfour, largely due to declines in employer-sponsored insurance coverage. See id. (noting a decline in employer-sponsored insurance). 
FPL. ${ }^{25}$ In Massachusetts, among the uninsured $41 \%$ have incomes below $200 \%$ of the FPL and $61 \%$ have incomes below $300 \%{ }^{26}$ Missouri has a higher percentage of lower income residents without insurance because Missouri is a poorer state: Its citizens earn less than those in Massachusetts, with the median income in Missouri $\$ 8,000$ less than in Massachusetts. ${ }^{27}$ In Missouri, 34\% of residents earn below $200 \%$ of the FPL compared with $30 \%$ in Massachusetts. ${ }^{28}$

\section{Figure 4. The Uninsured by Income in Massachusetts and Missouri Massachusetts}

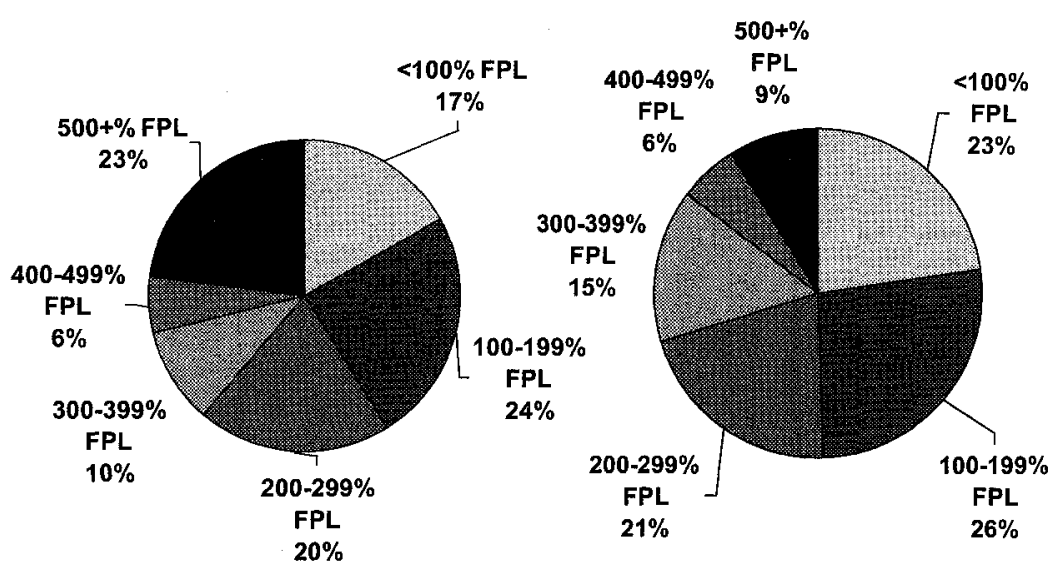

Source: Timothy McBride, Saint Louis University School of Public Health, analysis of CPS 2003-2004 data for non-elderly.

Yet, focusing just on the FPL as an indicator of financial need obscures regional variations in the cost of living. While $22 \%$ of Missourians earn too little to meet their basic needs-a large percentage and troubling figure-the numbers are even higher in Massachusetts: almost a third (31\%) of Massachusetts residents earn too little to meet their basic needs. ${ }^{29}$ A family of four in Boston needs $\$ 64,000$-almost $300 \%$ of the FPL - to pay for basic living expenses without factoring in

25. MCBRIDE ET AL., supra note 6, at 2-9 (discussing statistics resulting from Timothy McBride's analysis of CPS 2003-2004 data on the non-elderly population).

26. Id.

27. Id. at 26 .

28. $I d$.

29. Economic Policy Institute, Basic Family Budget Calculator (2007), http://www.epinet.org/ content.cfm/datazone_fambud_budget [hereinafter Family Budget Calculator]. 
health insurance premiums or other medical costs. ${ }^{30}$ That same family can meet their basic needs in St. Louis-not counting health insurance premiums or out-of-pocket medical costs--earning $\$ 41,000$, a little over $200 \%$ of the FPL. ${ }^{31}$ Cost of living differences are even more dramatic in rural areas. A family of four in rural Massachusetts needs to earn $\$ 55,560$ - two and one half times the FPL-to meet basic needs without counting health costs. ${ }^{32}$ That same family in rural Missouri can get by on about $\$ 31,000$ or one and a half times the FPL. ${ }^{33}$

Regional variations in cost of living may help explain why nearly $25 \%$ of Massachusans who lacked health insurance prior to passage of the Chapter 25 of the Acts of 2006 had incomes above $500 \%$ of the FPL, an income of $\$ 100,000$ for a family of four. In 2006 , the annual premium for employer-sponsored health insurance averaged $\$ 11,480$ for a family of four. ${ }^{34}$ This average premium cost is slightly more than the income for a full time minimum wage worker, almost $20 \%$ of the gross income of a family of four earning $300 \%$ of the FPL or $\$ 60,000$ a year, and almost $12 \%$ of the gross income of a family of four earning $500 \%$ of the FPL. ${ }^{35}$ Such premiums certainly price out those living at or under $300 \%$ of the FPL, but they can also price out those earning even higher incomes in high cost areas like Massachusetts. ${ }^{36}$

This survey of the health insurance landscape explains why states need a range of insurance expansion strategies to address different income, age, and employment demographics amongst the uninsured. First, expanding health insurance coverage requires mechanisms to

30. Sylvia Allegretto, ECON. POl'y InStit., Basic Family Budgets: Working FAMILIES' INCOMES OfTEN FAIL TO MEET LIVING EXPENSES AROUND THE U.S. 6 (2005), http://www.epi.org/content.cfm/bp165.

31. Family Budget Calculator, supra note 29.

32. Id.

33. Id. The 2004 federal poverty guideline for a family of four in the continental United States was $\$ 18,850$. U.S. Dep't of Health and Human Services (2004), http://aspe.hhs.gov/poverty/ 04poverty.shtml [hereinafter 2004 Poverty Guidelines].

34. Kaiser Family foundation \& HEalth RESEarch and Educational Trust, EMPLOYER HEALTH BENEFITS: 2006 ANNUAL SURVEY 1-2 (2006), www.kff.org/insurance/ 7527/upload/7527.pdf [hereinafter 2006 ANNUAL SURVEY]. Single coverage averaged about $\$ 4,242$ a year. Id.

35. Id. at 18 .

36. An Urban Institute analysis, based on the previous experiences of Hawaii, Minnesota, Tennessee, and Washington, suggests that premiums equal to $5 \%$ of income will price more than $80 \%$ of potentially eligible families out of Medicaid. Leighton Ku \& Teresa Couglin, Sliding-Scale Premium Health Insurance Programs: Four States' Experiences, 36 INQUIRY 471, 477 (1999); see also LeIghton KU \& VICTORIA WACHINO, CTR. ON BUDGET \& POL'Y PRIORITIES, THE EFFECT OF INCREASED COST-SHARING IN MEDICAID: A SUMMARY OF RESEARCH FINDINGS 7-9 (2005), http://www.cbpp.org/5-13/05health2.pdf (reviewing the effect of premiums on Medicaid participation in several states). 
subsidize health insurance premiums for those who cannot afford the full cost. Those with incomes below $100 \%$ of the FPL certainly need assistance. However, families with incomes between 200 and $300 \%$ of the FPL also have little-if any-income left after meeting other necessary expenses to cover health insurance premiums. Substantial premium support is needed to make health insurance affordable for these lower income Americans.

Second, workers of modest means earning between 300 and $500 \%$ of the FPL, particularly those employed by small firms, also have difficulty finding affordable health insurance. Without some employer contribution these workers may also be priced out of health insurance.

Third, we need employers who already subsidize employersponsored insurance to continue to contribute to their employees' health insurance. Most people in this country get health insurance through their employers and employer contributions play a crucial role in making health insurance affordable for most American families.

Fourth, expanding health insurance requires mechanisms to prompt both large and small employers who do not presently contribute toward their employees' health insurance to do so. Encouraging large employers to contribute toward their employees' health insurance helps level the playing field among large employers. Bringing in contributions from small employers helps stabilize employer-sponsored insurance as employment shifts from large to small firms.

Health insurance rates among smaller employers are a critical consideration in health insurance reform efforts because small employers face particular problems in purchasing group insurance. Their premiums tend to be higher because administrative costs are dramatically higher in the small group market-25\% compared to $5 \%$ in the large group markets. ${ }^{37}$ Moreover, when permitted by state law, insurers risk rate small groups charging higher prices to small businesses who have employees with ongoing health needs often pricing them out of the group health insurance market.

Reform efforts aimed solely at increasing health insurance coverage among those who work for large employers can have a significant impact on uninsurance rates-almost $30 \%$ of uninsured workers in Missouri work for very large firms of over a thousand workers. ${ }^{38}$ However, these efforts will not solve the problem for most uninsured workers.

37. Steffie Wollhandler et al., Costs of Health Care Administration in the United States and Canada, 349 NEW ENG. J. MED. 768, 771 (2003).

38. Timothy MCBride et. Al., The Massachusetts Plan: A MOdel for Missouri? 11 (2006), http://www.mffh.org/MassachusettsPlanModelMissouri.pdf. 
Fifth, increasing health insurance coverage also requires mechanisms to bring younger, healthier, lower cost individuals into public and private health insurance pools to help reduce the per person cost of coverage and to assure that people get preventive care. ${ }^{39}$ Attracting healthy peopleand their premium contributions-into health insurance pools also eliminates the problem posed by "free riders" who have access to affordable health insurance but choose not to participate, and then have inadequate personal income to cover the cost of services when they get sick. $^{40}$

The Massachusetts Model is a comprehensive reform initiative that uses a variety of strategies to address these different issues. All are incremental approaches that build on existing public Medicaid coverage and private employer-sponsored and individual insurance markets.

\section{ADAPTING THE MASSACHUSETTS MODEL TO OTHER STATES: THE LEGAL FRAMEWORK}

Chapter 58 of the Acts of 2006, the legislation creating the Massachusetts Model of health reform, is a seemingly giddy array of Medicaid changes, subsidized insurance offerings, insurance market reforms, safety-net changes, individual and employer mandates, and more. ${ }^{41}$ Yet, at the core of the Massachusetts Model are five relatively straightforward health insurance reform strategies. Three voluntary strategies are designed to make health insurance more affordable for both individuals and businesses: (1) a Medicaid expansion covers the lowest income adults and children up to $300 \%$ of the FPL; (2) a Private Insurance Premium Assistance program offers sliding scale coverage to adults with incomes up to $300 \%$ of the FPL; and (3) a voluntary Private Insurance Purchasing Pool makes group insurance more affordable for small businesses and individual policies more affordable for those earning over $300 \%$ of the FPL. ${ }^{42}$ Two mandatory strategies-an employer mandate and an individual mandate-encourage individuals to purchase insurance and employers to contribute toward the cost of

39. Joint Caucus for House Members, Health Care Reform: Conference Committee Bill Massachusetts Legislature, Apr. 3, 2006, at 13, http://www.mass.gov/legis/presentation.pdf [hereinafter Joint Caucus].

40. For a discussion of health insurance from the workers' perspective, see generally Claudia L Schur et al., Workers' Perspectives on Mandated Employer Health Insurance, HEALTH AFF., WEB EXCLUSIVES, Mar. 2004, w4.

41. McDonough et al., supra note 2, at w420.

42. See MCBRIDE ET AL., supra note 38, at app.A. 
employer-sponsored insurance. ${ }^{43}$ The employer and individual mandates establish a legal environment that encourages health insurance participation and also create opportunities for raising revenues to help fund subsidized Medicaid and Premium Assistance coverage for lower income residents.

This section examines the legislative and regulatory framework needed to create these five reform initiatives identifying which details are set forth in Chapter 58 and which are left to be developed during the implementation process. This section also identifies the statutory and regulatory framework that other states need to put in place if they wish to replicate the Massachusetts Model.

\section{A. Voluntary Strategies Designed to Make Insurance More Affordable}

1. Medicaid

First, Chapter 58 expands Massachusetts's Medicaid and State Children's Health Insurance Program (SCHIP) program, called MassHealth, to the maximum extent permitted by federal law and authorized by the Commonwealth's Section 1115 Medicaid Waiver. ${ }^{44}$ The statute expands MassHealth to cover children up to $300 \%$ of the FPL and adults who are parents, elderly, long term unemployed, and HIV+ up to $200 \%$ of the FPL. Children and adults with disabilities at any income level can pay a sliding scale premium to buy into MassHealth. ${ }^{45}$ The

43. Id.

44. MCBRIDE ET AL., supra note 6, at 12 tbl.8; see also, Federal Financial Participation in State Assistance Expenditures, FY 2006, http://aspe.os.dhhs.gov/health/fmap06.htm.

45. Prior to reform, MassHealth provided Medicaid and SCHIP coverage for children with incomes up to $200 \%$ of the FPL, the upper limit allowed by federal statutory law. Massachusetts has a Section 1115 Waiver that allows it to cover more categories of adults and at higher income limits than those authorized by the federal Medicaid Act. Thus Massachusetts covered not just adults who are parents, disabled and elderly but also adults who are long term unemployed and those who are HIV+ with incomes up to $200 \%$ of the FPL. The Massachusetts Waiver also authorized the Commonwealth to extend MassHealth coverage to disabled children and adults who buy-in to MassHealth on a sliding premium scale with no upper income limit. Chapter 58 expands MassHealth Medicaid and SCHIP eligibility for children from $200 \%$ to $300 \%$ of the FPL. An Act Providing Access to Health Care, supra note 1, ch. $118 \mathrm{E}, \S 9 \mathrm{~A}$. For adults, Chapter 58 removes enrollment caps that had resulted in waiting lists for some categories of adults. Id. $\S 107$. It also expands parent eligibility for Insurance Partnership Premium Assistance, a program that subsidizes employer provided health insurance, from 200 to $300 \%$ of the FPL. Id. $\S 9$ C. The legislation also earmarks $\$ 3$ million in state funds for outreach and enrollment activities by hospitals, community clinics and community based organizations. Id. $\S 104$. In fact, as far-reaching as the MassHealth expansions may seem, most of those to be newly covered by Medicaid and SCHIP under the Massachusetts Model-50,000 out of 92,500-are children and parents already eligible but not enrolled. Press Release, Commonwealth of Mass., Survey Reveals 88,000 Reduction among State's Uninsured (Aug. 28, 2006), http://www.mass.gov/?pagelD=pressreleases\&agId=Eeohhs2\&prMod 
legislation expands the Medicaid benefits package to include all optional as well as mandatory services allowed by the federal Medicaid Actincluding dental services, dentures, and eyeglasses. ${ }^{46}$ It also raises MassHealth reimbursement rates closer to Medicare rates to ensure that physicians and hospitals will participate in the expanded program and ties future rate increases to performance standards. ${ }^{47}$

Maximizing Medicaid and SCHIP coverage is a savvy fiscal move for states looking to expand health insurance coverage because the federal government matches every dollar the state spends on Medicaid/SCHIP. While the federal Medicaid and SCHIP rate varies by state, the average federal match rate is $60.19 \%$ for Medicaid and $72.13 \%$ for SCHIP. ${ }^{48}$ The Massachusetts rate is $50 \%$ for Medicaid and $65 \%$ for SCHIP. ${ }^{49}$

However, state Medicaid and SCHIP expansions are circumscribed by parameters set forth in the federal Medicaid and SCHIP law. The federal Medicaid statute gives states considerable flexibility to expand Medicaid to cover a long list of optional eligibility groups and categories of coverage, but states must obtain a waiver from the Secretary of Health and Human Services ("HHS") to use Medicaid or SCHIP to cover individuals and services not otherwise authorized by federal law. Most of the Massachusetts Medicaid and SCHIP expansions are authorized by federal Medicaid and SCHIP law, but some elements require a Section 1115 Waiver, a type of waiver which gives the Secretary of HHS broad authority to waive provisions of the federal Medicaid and SCHIP laws but also requires the state to document that the cost of operating under the waiver will be budget neutral in terms of federal matching dollars.

The federal Medicaid Act grants states looking to copy the Massachusetts Model sufficient authority to expand Medicaid income eligibility for parents and the elderly up to $100 \%$ of the FPL and as high

Name $=$ eohhspressrelease \&prFile $=$ pr_060828_uninsured_numbers_reduced.xml.

46. An Act Providing Access to Health Care, supra note $1, \S 53$. The Massachusetts legislation restored optional services for adults eliminated in 2002, including adult dental services, dentures, and eyeglasses.

47. Id. $\S 13 \mathrm{~B}$. The statute raises MassHealth provider reimbursement rates from $80 \%$ to $90 \%$ of Medicare rates, and ties future Medicaid rate increases to specific performance goals related to quality, efficiency, reduction of racial and ethnic disparities, and improved outcomes for patients. Id.

48. See Notice of Federal Financial Participation in State Assistance Expenditures, 69 Fed. Reg. 68,370 (Nov. 24, 2004) (listing percentages for the fifty states and the District of Columbia for October 1, 2005 through September 30, 2006).

49. Id. In Missouri, the federal share is $61.93 \%$ for Medicaid and $73.35 \%$ for SCHIP. MCBRIDE ET AL., supra note 6, at 12 tbl.8.; see also, Federal Financial Participation in State Assistance Expenditures, FY 2006, http://aspe.os.dhhs.gov/health/fmap06.htm. 
as $250 \%$ of the FPL for those with disabilities. ${ }^{50}$ However, states will need Section 1115 Waiver approval to extend Medicaid to adults who are not parents, elderly, or disabled. ${ }^{51}$ States also need CMS waiver approval to expand Medicaid and SCHIP eligibility for children above $200 \%$ of the FPL.

\section{Private Insurance Premium Assistance}

Chapter 58 also creates a Private Insurance Premium Assistance program that qualifies for federal Medicaid matching funds. Called the Commonwealth Care Health Insurance Program, the Premium Assistance Program subsidizes private insurance premiums for uninsured adults with household incomes up to $300 \%$ of the FPL who are not eligible for Medicaid. $^{52}$

50. See 42 U.S.C. $\$ 1396(a)(10)(A)(i i)$ (2000) (describing which groups can be added for coverage at the option of the states); 42 C.F.R. $\$ 435.230$ (2006) (describing optional coverage for the elderly and disabled); see also ANDY SCHNEIDER ET AL., THE KAISER COMM'N ON MEDICAID \& THE UNINSURED, THE MEDICAID RESOURCE BOOK 10, 13-14 (2000), http://www.kff.org/ medicaid/2236-index.cfm (discussing eligibility requirements for low income parents). The MassHealth eligibility category which allows children and adults with disabilities to buy in to Medicaid by paying a sliding scale premium is authorized by the Commonwealth's Section 1115 Waiver. States not wishing to apply for a waiver can use the federal Medicaid statute's optional Ticket to Work eligibility category to cover adults with disabilities with incomes up to $250 \%$ of the FPL. Statutes have great flexibility in defining the kind of work activities that allow people with disabilities to use this pathway to eligibility. For a detailed explanation of the relation of the Medicaid Buy-In Program to the Ticket-to-Work program, see SARAH R. DAVIS \& HENRY T. IREYS,

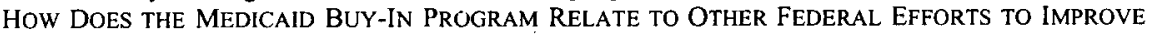
ACCESS TO HEALTH COVERAGE FOR ADULTS WITH DISABILITIES? (2006), http://www.mathematicampr.com/publications/pdfs/buyinprogram.pdf.

51. SCHNEIDER ET AL., supra note 50, at 16 (discussing extending Medicaid coverage using Section 1115 waivers). CMS has already approved Section 1115 waivers to allow several states to cover childless, non-disabled parents. It has also granted waivers to various states to expand eligibility levels for parents. For a full listing of waivers by state, see State Coverage Initiatives, Matrix Glossary, Medicaid, SCHIP, and Federal Authority, http://statecoverage.net/matrix/ waivers.htm.

52. An Act Providing Access to Health Care, supra note 1 , ch. $118 \mathrm{E}, \S 3$. Since the Massachusetts legislation expands Medicaid/SCHIP coverage to children up to $300 \%$ of the FPL, the private insurance premium assistance program provides coverage for adults-both individual coverage and coverage for couples. The legislation provides that only uninsured individuals with household incomes up to $300 \%$ of the FPL who are not eligible for Medicaid or Medicare, and whose employers do not offer subsidized insurance qualify for the Premium Assistance Program. However, it also allows the directors of the programs to allow employees whose employers pay at least $20 \%$ of the cost for individual or $33 \%$ of the cost of family coverage may also participate, but the employer must contribute towards the cost of the Premium Assistance policy. This provision is designed to guard against "crowd-out," the concern that publicly subsidized health insurance will result in individuals dropping private coverage in favor of public coverage. Id. $\S 2$ (stating that the program "is designed to reach low-income uninsured residents and maximize their enrollment in the program") 
The Premium Assistance Program only insures adults because children are covered through Medicaid and SCHIP. It wraps around Medicaid eligibility for adults insuring that childless adults with incomes below $200 \%$ of the FPL who do not qualify for MassHealth as well as other uninsured adults with incomes between $200 \%$ and $300 \%$ of FPL who earn too much to qualify for MassHealth have a source of sliding scale insurance. ${ }^{53}$

The program is administered by a new independent public entity, the Connector Authority, in consultation with the state's Office of Medicaid, ${ }^{54}$ and only policies purchased through the Connector are eligible for Premium Assistance subsidies. ${ }^{55}$ Participating individuals pay their sliding scale premium, if any, to the Connector Authority which then pays the full premium amount to the private insurance plan. ${ }^{56}$ To ease the transition to a private insurance-based system for the state's safety net providers, the statute specifies that for the first three years of the program, as long as enrollment targets are met, only managed care organizations participating in MassHealth will be permitted to sell Premium Assistance policies. ${ }^{57}$

The legislation specifies that Premium Assistance policies offered to adults with incomes below $100 \%$ of the FPL are to have benefits and copayments similar to Medicaid coverage. ${ }^{58}$ It also stipulates that individuals with incomes below $100 \%$ of the FPL are eligible for full premium assistance, paying nothing towards the premium cost. ${ }^{59}$ The

53. Id. $\S 3$ (a). Uninsured residents of the state with incomes up to $300 \%$ of the FPL who are not eligible for MassHealth, SCHIP or Medicare may participate in the private insurance premium assistance program. Id.

54. Id. $\S 2$.

55. See id. (stating "subsidies shall only be paid on behalf of an eligible individual who is enrolled in a health plan that has been procured by the commonwealth health insurance connector under said chapter 176Q").

56. Id. (stating "subsidies shall only be paid on behalf of an eligible individual who is enrolled in a health plan that has been procured by the commonwealth health insurance connector under said chapter 176Q.")

57. An Act Providing Access to Health Care, supra note 1, ch. 176G.

58. Id. ch. $118 \mathrm{H}, \S 6$.

59. Id. Sliding scale premiums for those with incomes between 100 and $300 \%$ FPL will need to be set at a level that attracts participation. Some policy experts suggest that health insurance premiums need to be below $5 \%$ of income for individuals to consider premiums affordable. However, other studies show that even $5 \%$ may be too high a premium level for lower income Americans. A recent Urban Institute study of health insurance affordability concludes that the median employee contribution towards premiums represents $1.5 \%$ of income for single coverage and $3.0 \%$ for family coverage, a figure that some are now proposing as the appropriate premium contribution levels in Massachusetts. See JOHN HOLAHAN ET AL., SETTING a STANDARD OF AFFORDABILITY FOR HEALTH INSURANCE COVERAGE IN MASSACHUSETTS (2006), http://www. bcbsmafoundation.org/foundationroot/en_US/documents/affordability-aug06-FINAL.pdf. 
Connector Authority is responsible for developing sliding scale premiums and co-payments for those with incomes between 100 and $300 \%$ of the FPL. ${ }^{60}$ The legislation specifically prohibits Premium Assistance policies from imposing deductibles. ${ }^{61}$

The key legal issue for states interested in replicating the Massachusetts Private Insurance Premium Assistance Program is obtaining a Section 1115 Waiver from the Secretary of HHS to use federal Medicaid matching funds to finance the private insurance premium subsidies and to cover all adults up to $300 \%$ of the FPL. The federal government has approved an amendment to Massachusetts's Section 1115 Medicaid Waiver to allow the state to use federal Medicaid matching funds to help pay the costs of the Premium Assistance Program. ${ }^{62}$ This waiver includes permission to use federal Medicaid money to cover childless adults and to raise income eligibility levels for adults up to $300 \%$ of the FPL.

It seems likely that CMS will look favorably on other states' efforts to use federal Medicaid and SCHIP matching funds to finance private insurance subsides. CMS has actively promoted using Medicaid and SCHIP funds to support private insurance subsidies through its 2001 Health Insurance Flexibility and Accountability (HIFA) Section 1115 Waiver initiative. ${ }^{63}$ The agency has approved a number of state proposals to expand Medicaid eligibility using a variety of premium assistance models. ${ }^{64}$ Of course, the challenge for any 1115 Waiver application is the requirement for the state to show that the coverage expansion will be revenue neutral in terms of federal matching dollars, but the Massachusetts Waiver offers a template for other states' budget neutrality calculations. ${ }^{65}$

60. An Act Providing Access to Health Care, supra note 1, ch. $118 \mathrm{H}$.

61. Id. $\$ 6$.

62. Letter from Mark McClellan, Administrator, Dep't of Health \& Human Services, to Timothy Murphy, Secretary, Commonwealth of Massachusetts Executive Office of Health \& Human Services (July 26, 2006), http://www.hcfama.org/_uploads/documents/live/Waiver-Approval_ Letter.pdf.

63. Laura tobler, National CONFEREnCE of STATE Legislatures, hifa DEMONSTRATION INITIATIVE (2003), http:/www.ncsl.org/programs/health/hifa.htm. The Deficit Reduction Act (DRA) of 2005 expands states' ability to implement Premium Assistance programs for individuals already covered by state Medicaid programs. However, states still need CMS approval to use federal Medicaid funds to support Premium Assistance programs for the purpose of expanding Medicaid coverage.

64. National Academy for State Health Policy, Premium Assistance Toolbox for States, http://www.patoolbox.org/_docdisp_page.cfm?LID=A27DFE16-1F0F-4329-942794A17CF0547B.

65. Centers for Medicare and Medicaid Services, Research and Demonstration ProjectsSection 1115, http://www.cms.hhs.gov/MedicaidStWaivProgDemoPGl/03_Research\& DemonstrationProjects-Sectionl 1 15.asp (defining "budget neutral" as the demonstration project not 


\section{State-Authorized Private Insurance Purchasing Pool}

The third health insurance expansion strategy is a state-authorized Private Insurance Purchasing Pool, dubbed the Commonwealth Health Insurance Connector. The Purchasing Pool is designed to make health insurance more affordable for small businesses and those with incomes above $300 \%$ of the FPL who rely on individual policies. ${ }^{66}$ The Pool is administered by the Connector Board, the same independent public entity that administers the Private Insurance Premium Assistance Program. ${ }^{67}$ The Connector is not authorized to act as the purchaser for the Pool, instead it grants its seal of approval to products that may be sold through the Pool based upon standards it promulgates for cost and quality. ${ }^{68}$

Prior to passage of Chapter 58, Massachusetts already aggressively regulated the small-group and individual insurance markets requiring standardized policies, guaranteed issue, and modified community rated premiums. ${ }^{69}$ Health insurance premiums were not allowed to vary based upon health status, claims experience, or gender, although they did vary based upon age, family size, geographic location, and industry. ${ }^{70}$

Chapter 58 merges the small group and individual markets to create a larger insurance pool and greater economies of scale. Predictions were that the merger of the small group and individual markets would decrease the cost of individual insurance by as much as $25 \%$ while raising premiums for small employers slightly. ${ }^{71}$

Chapter 58 also authorizes reforms to the private insurance market designed specifically to make health insurance more affordable for

costing the Federal government more than it would cost without a waiver).

66. An Act Providing Access to Health Care, supra note 1, ch. 176Q.

67. Id. ch. $176 \mathrm{~J} \S 1$. Premiums could not vary based upon health status, claims experience, or gender, although they varied based upon age, family size, geographic location, and occupation.

68. Id . ch. $176 \mathrm{Q} \S 3(3)$. Chapter 58 authorizes the Connector to market policies to individuals and small groups in the newly merged, modified community rated market that meet standards it promulgates for high quality and good value. $I d$. $\S 5,10$. The reform legislation leaves in place almost all existing insurance mandates. However, it declares a moratorium on new mandates, and repeals the Commonwealth's "any willing provider" law so that HMOs and PPOs may sell plans with more restricted provider networks. Id. ch. 176G, §16A.

69. See MCBRIDE ET AL., supra note 38, at 7 App. D (identifying how Chapter 58, section 76 amends M.G.L. 176J(1) existing standards for "modified community rating").

70. MCBRIDE ET AL., supra note 6, at 21 . "The law also reduces waiting periods for those who have not had previous health insurance, while leaving in place existing limits on deductibles, copayments, and coinsurance." Id.

71. Joint Caucus, supra note 39 , at 4 ; see also GORMAN ACTUARIAL, LLC ET AL., IMPACT OF MERGING THE MASSACHUSETTS NON-GROUP AND SMALL GROUP HEALTH INSURANCE MARKETS 10 (2006), http://www.mass.gov/Eoca/docs/doi/Legal_Hearings/NonGrp_SmallGrp/FinalReport_12 26.pdf (predicting that by July 2007 , individual rates will drop $15 \%$ while the small group rate will rise $1.5 \%$ ). 
young adults. The legislation provides that young adults may continue on their parents' plans for up to two years after they are no longer dependents or until age 25 , whichever occurs first. ${ }^{72}$ It also authorizes the Connector to offer specially designed, lower-cost products for 19-26 year olds. ${ }^{73}$

The legislation also mandates that employers with eleven or more full time workers set up Section 125 cafeteria plans through the Internal Revenue Service to allow employees to use pre-tax dollars to purchase insurance. ${ }^{74}$ This helps reduce the cost of insurance for higher income individuals who contribute to employer-sponsored plans as well as individuals who use the Connector to purchase individual policies.

States like Massachusetts that already use modified community rating or some other method for setting premiums in the small group and individual markets should have statutory and regulatory frameworks in place to provide the administrative structure within which a Connectortype Purchasing Pool can operate. These states will need to consolidate their small group and individual markets, but their biggest challenge will be agreeing on the standards for coverage and cost of policies offered through the Pool, matters that Chapter 58 delegates to the Connector Board.

However, states like Missouri that allow insurers to risk rate in the individual and small group markets face different legal challenges in developing a Private Insurance Purchasing Pool. These states could merge their small group and individual markets, develop standardized policies, and institute modified community rating for all policies sold in the newly merged market. However, unlike the merger of Massachusetts's already community rated market-where predictions are that individual premium prices will fall substantially while small group prices will increase only fractionally, the move to market-wide community rating will initially result in increased premiums costs for many_likely half —of all policy holders.

72. An Act Providing Access to Health Care, supra note 1, ch. 175, $\$ 108$.

73. Id. ch. $176 \mathrm{~J}, \S 10$.

74. Id. ch. $151 \mathrm{~F}$. Section 125 plans do not require any employer contribution. Employers who do not set up Section 125 Cafeteria Plans will be assessed a "Free Rider Surcharge" if their employees are repeat users of the Commonwealth's Uncompensated Care Pool, costing the pool more than $\$ 50,000$ in one year. Id. ch. $118 \mathrm{G}, \S 18 \mathrm{~B}$. Employers are subject to the charge if their employees use the free care pool a total of five times per year in the aggregate, or if any one employee uses free care more than three times. This surcharge "shall be greater than $10 \%$, but no greater than $100 \%$ of the cost to the state" of the free care, with the first $\$ 50,000$ of costs exempted. Id. 
For states like Missouri that allow risk rating for the small group and individual markets, a more incremental step towards the Massachusetts Model would be legislation authorizing a voluntary Private Insurance Purchasing Pool that offers individuals and small groups access to a choice of standardized private insurance plans with premiums set at modified community rates while allowing the existing risk-rated small group and individual insurance markets to remain intact. In this scenario, the voluntary Purchasing Pool creates economies of scale and reduces administrative costs, but also acts as a large purchaser negotiating premium rates with private plans that wish to offer policies through the Pool.

A large, voluntary Private Insurance Purchasing Pool should be able to lower premium costs for individuals and small groups by lowering administrative costs, presently estimated to be as high as $25 \%$ in the individual and small group markets. ${ }^{75}$ Moreover, it may also be able to offer lower premium prices by spreading the risk - and the cost-among a large enough number of individuals to bring down the average premium price.

However, a voluntary Purchasing Pool operating in a state that allows risk rating in the individual and small group market must attract enough healthy individuals to be able to spread the costs of those with substantial medical needs. ${ }^{76}$ Modified community rated Purchasing Pool premiums must be low enough that healthy individuals will use the Pool rather than purchase risk-rated policies on their own, outside the Pool. This adverse selection problem always arises when voluntary purchasing pools must compete with risk-rated premiums.

A number of design features can help ensure that a voluntary pool enacted as part of a larger Massachusetts Model is large enough and stable enough to help counteract adverse selection. These include combining the subsidized Private Insurance Premium Assistance enrollees with the Private Purchasing Pool enrollees, marketing special plans through the Pool designed to attract healthier young adults, and implementing an individual mandate to encourage individuals who would otherwise go without insurance to purchase insurance. ${ }^{77}$ For example, in Missouri, a voluntary purchasing pool that combined small

75. Wollhandler et al., supra note 37, at 771 .

76. ElLIOT K. WiCKS, MisSOURI FOUNDATION FOR HEALTH, EXPANDING Coverage Through THE MisSouri CONSOlidated HEalth CARE Plan (MCHCP) 5 (2006).

77. LiSa Clemans-COPE et al., Missouri Foundation for HEalth, High-Deductible Health Plans with Health Savings accounts: Emerging Evidence and Outstanding ISSUES 5-7 (2006), www.mffh.org/CoverMol 0.pdf. 
businesses and individuals with subsidized Private Insurance Premium Assistance enrollees could cover as many as 500,000 working age, nondisabled adults. In a pool this large, risk should be spread broadly enough to allow the pool to negotiate less costly, more affordable premium rates. $^{78}$

\section{B. Mandates to Encourage Health Insurance Participation}

But voluntary health insurance cannot and will not result in universal health insurance coverage: There is no guarantee that the more healthy or the less wealthy will opt to purchase health insurance. In Massachusetts, predictions were that the three voluntary insurance expansion initiatives-Medicaid, Private Insurance Premium Assistance, and the Purchasing Pool-would likely reduce the number of uninsured by $40 \% .{ }^{79}$ While this is a substantial accomplishment, it would still leave 284,000 Massachusans uninsured. ${ }^{80}$

These figures - and this reality - prompted Massachusetts to move beyond voluntary health insurance expansions to mandate that both employers and individuals participate in the health insurance system or pay a penalty. Not only do the mandates help nudge the state toward one hundred percent health insurance coverage, but they also help stabilize the three health insurance pools created by the voluntary health insurance expansion initiatives. To a lesser degree, they also create opportunities for raising revenue to help finance MassHealth and Private Insurance Premium Assistance costs.

\section{Employer Mandate}

The Massachusetts employer "play or pay" mandate requires employers with eleven or more full-time equivalent employees to provide a "fair and reasonable" premium contribution toward their employees' health insurance or pay an annual "Fair Share Contribution"

78. The Missouri Consolidated Health Care Plan (MCHCP) presently covers 104,000 state employees, dependents and retirees and has been able to negotiate quite competitive per month premium rates. MCBRIDE ET AL., supra note 6, at 24.

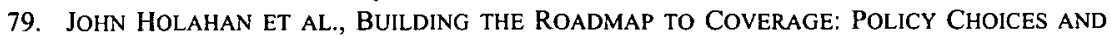
THE COST AND COVERAGE IMPLICATIONS 29 (2005). The Urban Institute used data showing that $9.4 \%$ of Massachusetts residents were uninsured and estimated that voluntary strategies would reduce that number to $5.7 \%$ leaving $60 \%$ of the uninsured still uninsured. Id. In terms of the number of uninsured voluntary initiatives could reduce the number of uninsured from 532,000 to 211,000 , but leave 321,000 people without health insurance. Id. at 7 .

80. Id. 
assessment of up to $\$ 295$ per employee. ${ }^{81}$ The legislation does not define a "fair and reasonable" employer contribution leaving that determination to be promulgated through rule making by a state agency, the Massachusetts Division of Health Care Financing and Policy. ${ }^{82}$

A penalty of $\$ 295$ per employee per year seems astonishingly low given that the average cost of single employer sponsored coverage was $\$ 4,242$ in $2006 .^{83}$ Yet, the low penalty is justified because it is based upon the estimated private-sector share of the average per worker cost for care paid for by the Commonwealth's Uncompensated Care Pool for workers whose employers do not provide health insurance. If Uncompensated Care Pool costs rise or fall in future years, the annual assessment will adjust accordingly.

The employer mandate was possibly the most hotly contested piece of the reform legislation. Some stakeholders felt strongly that employers should continue to play a role in financing health insurance coverage, while others-including Governor Romney, whose veto of the employer mandate was overridden by the legislature-were strongly opposed to an employer mandate. ${ }^{84}$ The continuing existence of the mandate paired with a low penalty is part of the political compromise that kept the mandate in the reform package.

Moreover, it remains unclear whether a state imposed employer "play or pay" mandate is preempted by the federal Employee Retirement Income Security Act of 1974 (ERISA). ${ }^{85}$ Many are hopeful that such "play or pay" provisions will not violate ERISA's prohibition on direct regulation of employer health plans, but the ultimate fate of these laws is yet to be determined by the courts. ${ }^{86}$ One side benefit of Massachusetts's low penalty is that no employer has challenged the provision: a low penalty is a political compromise.

Most importantly, though, an employer mandate cannot achieve universal coverage. An employer mandate only requires employers to

81. An Act Providing Access to Health Care, supra note 1, ch. $149, \S 188$.

82. Id. The statute specifically provides that the regulations setting a "fair and reasonable" employer contribution must be presented to the legislature for approval prior to implementation. Id.

83. 2006 ANNUAL SURVEY, supra note 34.

84. 'Pam Belluc \& Katie Zezima, Massachusetts Legislation on Insurance Becomes Law, N.Y. TIMES, Apr. 13, 2006, http://www.nytimes.com/2006/04/13/us/13health.html?_r=3\&oref=login\& oref $=$ slogin.

85. See Retail Indus. Leaders Ass'n v Fielder, 475 F.3d 180, 197 (4th Cir. 2007) (finding Maryland's Fair Share Health Fund Act was preempted by ERISA)

86. For an overview of state efforts to circumvent ERISA, see National Conference of State Legislatures, Massachusetts Passes Universal Health Care Package "An Act Providing Access to Affordable, Quality, Accountable Health Care" (2007), http://www.ncsl.org/programs/health/ massoverview.htm. 
offer health insurance to employees who qualify for employer sponsored coverage: it does not reach part-time, temporary, or seasonal workers who typically do not qualify for employer sponsored insurance. ${ }^{87}$ An employer mandate also has no impact on those workers who qualify for employer sponsored insurance but "opt out" of their employer's health plan and remain uninsured either because of cost concerns or a perceived lack of immediate need for medical care and insurance to cover the costs of care. Thus, the Massachusetts Model also incorporates an individual mandate as well as the employer mandate.

\section{Individual Mandate}

An individual mandate offers states a creative way to bypass the potential ERISA problems posed by an employer mandate and encourage employees to take up employer sponsored health insurance when it is offered. An individual mandate can specify a minimum level of benefits that must be held by each person, thus providing a strong-albeit indirect-incentive for employers to provide policies that would, at a minimum, allow their workers to meet that standard. ${ }^{88}$

The Massachusetts Model's individual mandate requires that adult residents of the Commonwealth "obtain and maintain" health insurance so long as "affordable" coverage meeting minimum standards is available. ${ }^{89}$ Residents must report compliance on their state income tax returns and the State Department of Revenue assesses income tax penalties against those who cannot document coverage. ${ }^{90}$ For 2007 the statutes set the penalty as loss of the personal income tax exemption, about $\$ 218$ for an individual and $\$ 437$ for a family. ${ }^{91}$ In 2008 and thereafter, the penalty rises to half the cost of a minimally acceptable "affordable" insurance plan. ${ }^{92}$

The newly authorized Massachusetts Health Insurance Connector Board is charged with developing regulations defining "affordable" and

87. Joint Caucus, supra note 39; JOHN HOLAHAN ET AL., ROADMAP TO COVERAGE: SYNTHESIS OF FINDINGS (2005).

88. HOLAHAN ET AL., supra note 87, at 11-12. Some have been concerned that employer mandates-or individual mandates that prompt employer contributions-would have a negative impact on employment and wages. However, studies in Massachusetts show that even a fairly robust pay or play provision has only a small marginal impact of the overall plan on economic activity, employment and wages. Id. at 11-12.

89. An Act Providing Access to Health Care, supra note 1, ch. $111 \mathrm{M}$.

90. Id.

91. $I d$.

92. Id. ch. $111 \mathrm{M}, \S 2 \mathrm{~b}$. 
minimally adequate health insurance. ${ }^{93}$ While Massachusetts, like every state, has a variety of mandated benefits that health insurance must cover, ${ }^{94}$ Chapter 58 contains no details about the scope of benefits, deductibles and out of pocket limits, or whether Healthcare Savings Accounts (HSAs) accompanied by catastrophic health insurance plans will satisfy the individual mandate's minimum coverage requirements. ${ }^{95}$ The legislation leaves these details to the newly formed Connector Board and sets in motion an ongoing public dialogue about what kind of insurance is adequate and affordable.

Some commentators question whether the Massachusetts individual mandate will actually result in universal coverage, pointing out that since the statutory penalty is only half the cost of purchasing health insurance deemed to be "adequate" and "affordable" some-and maybe manyMassachusans may choose to pay the penalty rather than purchase health insurance. ${ }^{96}$ Proponents of the Massachusetts legislation acknowledge this limitation, but hope that the individual mandate will set in motion an ongoing public conversation which prompts creation of heath insurance products that people will want and be able to purchase.

93. Id. Regulators are debating a variety of approaches to defining affordability including using Medicaid and SCHIP standards, average household budgets (as a means to determine the income available to pay for health insurance), and current spending on private health insurance coverage (as an indicator of the amount that individuals and families are willing and able to pay). HOLAHAN ET AL., supra note 59, at 6 . The statute does not require that "affordability" levels match the rates for the sliding fee Premium Assistance program. However, the Connector Board is charged with developing both levels and expectations are that the Board will set affordability rates that match the sliding scale rates. Commonwealth Health Insurance Connector Authority, Affordability Standards Recommended to Connector Board (2007), http://www.mass.gov/Qhic/docs/ Affordability_pr_4.11.07.doc.

94. See HeAlth CARE ACCESS AND AfFordability CONFERENCE COMMITTEE RePORT (2006), http://www.mass.gov/legis/summary.pdf. Chapter 58 also places a moratorium on new state legislatively imposed health insurance benefits through 2008 .

95. NATIONAL CONFERENCE OF STATE Legislatures, 2004-2006 STATE LEgislation ON Health Care Savings accounts and Consumer-Directed Health Plans (2006).

96. "The requirement has been likened to the requirement imposed on motorists to obtain automobile insurance." Press Release, Mintz Levin, Massachusetts Enacts Landmark Health Care Reform Bill: An Overview of H. 4850, An Act Providing Access to Affordable, Quality, Accountable Health Care (Apr. 21, 2006), www.mintz.com/news/news/657/ Massachusetts_Enacts_Landmark_Health_Care_Reform_Bill_An_Overview_of_H_4850_An_Act_ Providing_Access to_Affordable_Quality_Accountable_Health_Care. In Massachusetts, the penalty for violating the affordable insurance mandate is equivalent to only $50 \%$ of the cost of affordable insurance. Id. When the cost of non-compliance is less than the cost of complying with the law, people are more likely to pay the penalty rather than obtain insurance. 


\section{In Sum}

Thus, replicating the Massachusetts Model in other states requires statutory and regulatory authority for a variety of health insurance expansion building blocks. First, states need statutory authority to expand Medicaid and SCHIP up to the maximum levels allowed by federal law and available Section 1115 Waivers. Second, state legislation and federal waiver approval is needed to create a Medicaidfunded Private Insurance Premium Assistance Program to subsidize health insurance for those with incomes up to $300 \%$ of the FPL who are not eligible for Medicaid or other public coverage. Third, statutory authority is required to create a Private Insurance Purchasing Pool for those with incomes over $300 \%$ of the FPL who depend on the small group and individual markets for health insurance. Finally, state law needs to create both an employer and an individual "play or pay" mandate to help bring healthier individuals into these health insurance pools to make them larger and more stable so that the costs of health insurance are more affordable for all.

Replicating the statutory and regulatory framework of the Massachusetts Model requires an understanding of Medicaid law and the state's health insurance regulatory environment. Ultimately, though, replicating the legal framework of the Massachusetts Model is not difficult. What may be more challenging is financing the costs of the reform strategies.

\section{ADAPTING THE MASSACHUSETTS MODEL: COSTS AND FinANCING}

Politics and ideology aside, the greatest challenge that Missouri and other states face in trying to duplicate a Massachusetts Model of health reform are the costs and public financing needed to support the Model. Massachusetts was able to develop consensus, in part, because the Model does not impose substantial new costs on employers, individuals, or the state. The public funding is made easier because more than half of the public costs are covered through federal Medicaid and SCHIP matching funds. Financing the state's share of the costs is predicted to require only $\$ 125$ million annually in new state funding because almost all the state's share of the public costs can be paid for by shifting $\$ 1$ billion from an existing uncompensated care pool into insurance subsidies. ${ }^{97}$

97. Holahan \& Blumberg, supra note 3. 
Replicating the Massachusetts Model will almost certainly be more costly for other states. Massachusetts has one of the lowest uninsured rates in the country which means fewer residents need health insurance coverage. Moreover, Massachusetts is also a high income state with fewer very poor and near poor uninsured residents needing publicly funded private premium assistance, Medicaid and SCHIP. Finally, Massachusetts is likely the only state that has a $\$ 1$ billion uncompensated care pool that can be shifted to fund insurance subsidies.

Understanding the costs and financing options for duplicating the Massachusetts Model in Missouri offers lessons for other states that may look more like Missouri than Massachusetts. Missouri is typical of many states. It has a relatively high percentage of very poor and near poor residents who will need public funding to help cover all or part of the costs for health insurance. It does not have an uncompensated care pool, but, like other states, it does appropriate substantial funding for uncompensated care. Missouri voters, like those in many other states, are loath to impose higher income taxes on residents, but a variety of other targeted revenue sources could fund the state's share of a Massachusetts Model of health reform in Missouri. What is possible in Missouri may be possible in other states as well.

To move Missouri to universal health insurance requires covering 847,000 uninsured children and adults. ${ }^{98}$ In Missouri, a Massachusetts Model of health reform covers the uninsured as follows. The Medicaid and SCHIP expansion covers $254,000-30 \%$ of the uninsuredincluding all children with incomes up to $300 \%$ of the FPL and the lowest income adults. ${ }^{99}$ The Private Insurance Premium Assistance

98. MCBRIDE ET AL., supra note 38 App. B. Simulated Eligibility for Insurance and Costs of Coverage under a Massachusetts-Style Plan in Missouri, at note 53 et seq. All figures are for 2006. Data is based upon individual level data drawn from the Current Population Survey (CPS), supplemented with data to take account of 135,000 Missouri residents who lost Medicaid coverage in 2005. Id.

99. Id. at 13, 17-21. In setting income cut-offs for Medicaid and SCHIP eligibility we followed the parameters of the federal Medicaid Act and Missouri's existing Section 1115 Waiver to reduce, as much as possible, the need for Missouri to obtain new Section 1115 waivers. Thus, we assumed that Medicaid and SCHIP would cover children up to $300 \%$ of the FPL, parents and the elderly up to $100 \%$ of the FPL, and adults with disabilities up to $250 \%$ of the FPL. Missouri already covers children up to $300 \%$ of the FPL pursuant to a Section 1115 Waiver. Presently, Missouri's income eligibility limits for parents and other adults are extremely low: $18-22 \%$ of the FPL for parents and $85 \%$ of the FPL for the disabled and elderly. MO. REV. STAT. $\$ 208.151$ (2006). Missouri has a Section 1115 Waiver to cover other groups of parents including non-custodial parents, but the state does not have Section 1115 approval to cover childless adults or HIV+ individuals before they become permanently and totally disabled. Missouri's Section 1115 Waiver already authorizes parent eligibility up to, and in some cases above, $100 \%$ of the FPL. The budget neutrality calculations that govern that waiver would likely accommodate even higher income limit for parents than those authorized by the federal Medicaid statute and implementing regulations. MCBRIDE ET AL., supra 
Program covers 398,000 adults $-47 \%$ of the uninsured-wrapping around Medicaid eligibility to cover other uninsured adults with incomes up to $300 \%$ of the FPL. ${ }^{100}$ The Private Insurance Purchasing Pool covers 93,170 people $-11 \%$ of the uninsured - with incomes over $300 \%$ of the FPL who now rely on the small group or individual market. ${ }^{101}$ We calculate that the individual mandate will prompt all those with incomes over $300 \%$ of the FPL who are presently offered employer sponsored health insurance but not enrolled to do so, resulting in $12 \%$ of the currently uninsured or 101,640 people obtaining employer sponsored coverage. We assume that the employer play or pay mandate would not prompt any employers who do not presently offer health insurance to begin doing so. Instead, we assume that these employees will obtain individual coverage through the newly created Private Insurance Purchasing Pool.

\section{Figure 5. How the Massachusetts Model Covers the Uninsured in Missouri.}

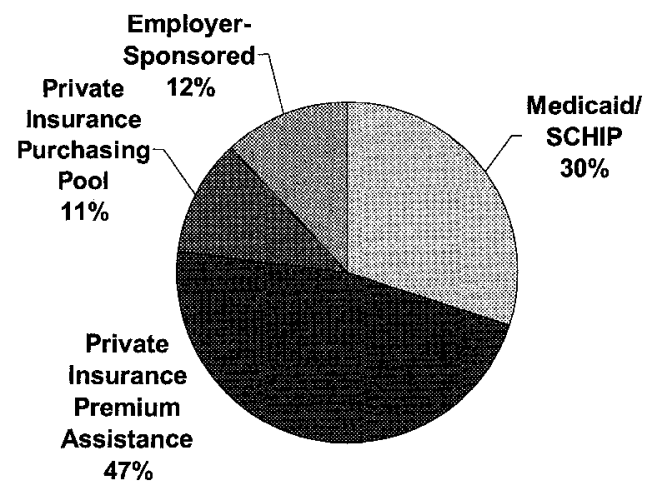

Source: Timothy McBride et al., The Massachusetts Plan: A Model for Missouri? (2006).

note 38 , at tbl.III-1.

100. MCBRIDE, et al., supra note 38, at 13-17. In selecting income cut-offs for the Medicaid and SCHIP eligibility we followed the parameters of the federal Medicaid Act and Missouri's existing Section 1115 Waiver to reduce, as much as possible, the need for the state to obtain new Section 1115 waivers. However, for cost purposes, the eligibility line between Medicaid and the Private Insurance Premium Assistance Program is unimportant because in determining costs we used the same per person cost estimates for both programs.

101. Id. at $13,22-23$

102. Id. at 25 . 
To calculate the costs of using a Massachusetts Model to cover the uninsured in Missouri, we multiplied the number of people newly covered through each expansion strategy by the cost per person. ${ }^{103} \mathrm{We}$ estimated the per person cost of new coverage using historic costs for coverage in the state's Medicaid, SCHIP and state employee's health insurance programs. ${ }^{104}$ We increased historic Medicaid rates to reflect a Medicaid benefit package that covered all services authorized by the federal Medicaid statute. ${ }^{105}$ Since Missouri, like Massachusetts, has very low Medicaid physician reimbursement rates which have resulted in limited physician participation, the cost estimates include a Medicaid physician rate increase to bring payment rates closer to Medicare rates. ${ }^{106}$ We also estimated across the board savings of $6 \%$ for all forms of health insurance-individual, group, Medicaid, and SCHIP—as a result of larger risk pools, administrative efficiencies, and reduced cost shifting that result from universal coverage. ${ }^{107}$ Other analysts calculate even higher cost savings from universal coverage $-10 \%$ or even more-but we purposely chose a more conservative figure. ${ }^{108}$

Using these figures, we calculate the net costs of covering all uninsured Missourians using a Massachusetts Model of health reform to be $\$ 2.6$ billion in private and public funds. ${ }^{109}$ The per person cost is $\$ 3,070$ a year, substantially below the $\$ 4,242$ average cost for employer-

103. Id. at 53-54 App.B.

104. Id. at 53 . The per member per month figures used are as follows: $\$ 350$ for non-disabled adults using employer-sponsored insurance, Private Purchasing Pool, or Premium Assistance coverage for those over $100 \%$ of the FPL; $\$ 255$ for non-disabled adults using Medicaid or Premium Assistance up to $100 \%$ of the FPL; $\$ 1261$ for disabled adults; $\$ 149$ for children with incomes up to $100 \%$ of the FPL using Medicaid; $\$ 111$ for children using SCHIP; $\$ 150$ for the cost of adding dependent coverage in the state employee plan. Id. at 53 .

105. Id. at 19. Missouri eliminated a number of optional services for adults in 2005 because of budget concerns including dental care, rehabilitation services, durable medical equipment, and physical, occupational, and speech therapy. The cost estimates assume these services are reinstated. Id.

106. Id. at 55. Missouri has one of the lowest Medicaid physician reimbursement rates in the country, paying only $55 \%$ of Medicare rates. As a result, many physicians limit their participation in Medicaid creating access problems for those with Medicaid coverage. MEDICAID REPORT, supra note 8 , at 25 .

107. See MCBRIDE ET AL., supra note 38, at 55 App.B ("as cost shifting from the uninsured ends and as efficiency gains from buying insurance through a Purchasing Pool takes hold.").

108. See, e.g. KenNeth Thorpe, A Universal Health Care Plan for Missouri (2003), $\mathrm{http}: / / \mathrm{www} . \mathrm{mffh} . \mathrm{org} /$ ShowMe3.pdf.(estimating savings from universal coverage in the range of 10 $15 \%)$.

109. See MCBRIDE ET AL., supra note 38, at 30 (detailing the net cost estimates and assumptions of the simulations used to derive the estimates shown here). All cost estimates are for 2006 and assume the initiative is adopted and implemented that year. Costs are not projected forward to future years. Id. The Massachusetts Model is unlikely to result in one hundred percent health insurance coverage, but estimates assume that it captures the maximum costs-both public and private-of implementing such a Model. 
sponsored individual coverage in 2006. ${ }^{110}$ In terms of sources of funding, implementing a Massachusetts Model of health reform in Missouri produces a net savings to employers. The costs of the new coverage are divided among individuals whose premiums cover $12 \%$, the state government pays $34 \%$, and the federal government covers $54 \%$ of the costs through federal Medicaid and SCHIP match.

\section{Figure 6. Net Costs of Covering the Uninsured in Missouri, by Source of Funding (in millions of dollars).}

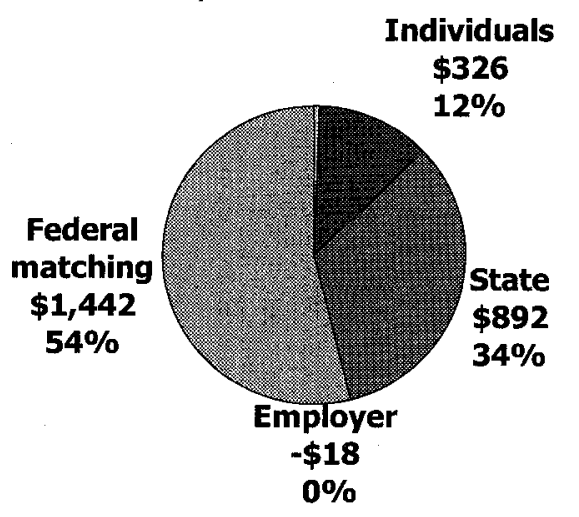

Source: Timothy McBride et al., The Massachusetts Plan: A Model for Missouri?, The Missouri Foundation for Health (2006).

Massachusetts style health reform offers a net savings to Missouri employers even though employers who do not presently contribute to employer sponsored insurance will see an increase in costs of approximately $\$ 599$ million. Their new costs are more than offset by cost savings to employers who already subsidize employee health insurance. Overall, employers should see savings of approximately $\$ 617$ million. We assumed that the employer "play or pay" mandate would not prompt any employers presently not offering health insurance to do so. Instead, we factored the $\$ 295$ per employee play or pay penalty into their costs. ${ }^{111}$

Missouri residents will pay for $12 \%$ of the costs of covering the uninsured though increased premium costs will run $\$ 326$ million. Overall premiums will drop by $6 \%$ under a Massachusetts Model, but

110. Id. at 30 . This figure is derived by dividing $\$ 2.6$ million in net costs by 847,000 uninsured.

111. Id. at $56-57$. 
more individuals will purchase insurance through employer sponsored insurance, the Private Insurance Purchasing Pool and the Private Insurance Premium Assistance Program. ${ }^{12}$ The bulk of these premium costs for individuals - $61 \%$ - are shouldered by the $12 \%$ of uninsured Missourians with incomes over $300 \%$ of the FPL. ${ }^{113}$ Our cost estimates assume that those with incomes below $300 \%$ of the FPL will contribute sliding scale premiums in the Private Insurance Premium Assistance program ranging from $0 \%$ for those with incomes below $100 \%$ of the FPL and rising to $5.8 \%$ of income for those earning $300 \%$ of the FPL. ${ }^{114}$ For example, a person earning $200 \%$ of the FPL- $\$ 19,800$ a year for a single person-would pay about $\$ 25$ per month or roughly $2.9 \%$ of their income towards their health insurance premiums. ${ }^{115}$

A full $88 \%$ of the costs of funding the Massachusetts Model in Missouri are financed by the state and federal governments. ${ }^{116}$ The annual public financing needed to implement a Massachusetts Model in Missouri is $\$ 892$ million in state funds and $\$ 1.4$ billion in federal matching funds for Medicaid, SCHIP, and the new Medicaid-funded Premium Assistance Program. ${ }^{117}$

Missouri does not have an uncompensated care pool that can be used to help fund its share of the first year's cost for a Massachusetts Model of health reform, but the state does allocate $\$ 327.3$ million in state and local funds to pay for uncompensated care, money that could be shifted to help subsidize health insurance. $^{118}$ In 2005, Missouri contributed \$160.7 million toward Medicaid Disproportionate Share Hospital (DSH) payments to help reimburse hospitals for the costs of caring for uninsured patients. ${ }^{119}$ It contributed another $\$ 14.8$ million toward DSH payments that fund a Medicaid Section 1115 Waiver that pays for outpatient care for the uninsured in the St. Louis area. ${ }^{120}$ Finally, it spent

112. Id. at 53 .

113. See $i d$. (noting that "only about $39 \%$ of the $\$ 544$ million is bome by those between 100 and $300 \%$ of FPL").

114. Id. at 31 tbl.4-1.

115. Id. at 31. The sliding scale contribution is as follows: $0-100 \% \mathrm{FPL}, 0.0 \% ; 101-125 \%$, $0.7 \% ; 126-150 \%, 1.5 \% ; 151-175 \%, 2.2 \% ; 176-200 \%, 2.9 \% ; 201-225 \%, 3.6 \% ; 251-275 \%, 5.1 \%$, $276-300 \%, 5.8 \%$. Id.

116. Id. at 30 .

117. Id. "Currently, $\$ 335.4$ million in federal Medicaid and SCHIP matching funds already come to the State to help cover the cost of the uninsured. New matching funds of $\$ 1.07$ billion would be needed, some of which would likely need to be approved pursuant to a Medicaid Section 1115 waiver." Id. at 31 .

118. Id.

119. MisSOURI FOUNDATION FOR HEALTH, THE COST OF CARE FOR MISSOURI'S UNINSURED 18 tbl.l1 (2006).

120. Id. 
an additional $\$ 151.8$ million in state, county and local funds to fund other health care services to the uninsured, including community clinics and hospitals. ${ }^{121}$ Shifting this state and local money to fund insurance coverage rather than paying institutions to care for the uninsured would cover more than a third of the funding needed to cover the states net cost to implement the Massachusetts Model. ${ }^{122}$

However, Missouri would still need $\$ 564.7$ million in new state revenue to fund its share of the costs of a Massachusetts Model of health reform. ${ }^{123}$ Over half a million dollars in new state funding is certainly a challenge, but it is a relatively modest amount when compared to Missouri's gross state product of $\$ 226$ billion. ${ }^{124}$ While Missouri legislators have been loath in recent years to impose general state income taxes, targeted sales taxes on medical care, health insurance premiums, or smoking could raise more than enough new state revenue to cover the state's share of a Massachusetts Model.

Missouri presently does not tax sales of most services including medical services. A $2 \%$ sales tax on all medical services would raise $\$ 628.4$ million, more than enough to fully fund the state's share for a Massachusetts Model. ${ }^{125}$ Such a sales tax would raise the price of medical services, but the reform is predicted to produce a $6 \%$ cost savings so consumers should still see an overall drop in health insurance and medical costs even if the plan is funded by a new medical services tax.

121. Id. Unlike the state funding for Medicaid DSH, these funds are presently not matched by federal Medicaid dollars. This money, if used to expand Medicaid or support a federally-approved Private Insurance Premium Assistance program, could draw new federal Medicaid dollars to support universal coverage in Missouri.

122. Missouri needs a Section 1115 Waiver to use DSH funds to pay for health insurance rather than hospital care, but CMS has approved a number of such waivers and President Bush has endorsed this approach. KAISER FAMILY FOUNDATION, THE AFFORDABLE CHOICES INITIATIVE: AN OVERVIEW (2007), http://www.kff.org/uninsured/upload/7637.pdf.

123. Id.

124. Missouri Economic Research and Information Center, Gross Domestic Product Data Series, 2006 Estimates, http://ded.mo.gov/researchandplanning/indicators/gsp/index.stm.

125. ECON. \& POL'Y ANALYSIS RES. CTR., TAX EXPENDITURE REPORT: 2007 (2007), http://eparc.missouri.edu/Publication/TAXESP/sales.pdf. Currently, Missouri generally taxes sales of goods but not sales of services. At present, only eleven services are taxed including services such as pet grooming, marina services, and residential gas. Sorting out the public policy issues on taxing medical care requires balancing competing goals and issues. On the one hand, sales taxes tend to be regressive and impact low-income families more, and taxation of medical services can sometimes tax necessities or life-sustaining services. On the other hand, Medicaid, SCHIP, and the Premium Assistance program should help cushion the impact on those with incomes up to $300 \%$ of the FPL. Also, much research shows that more medical spending is consumed as a result of incentives in the health care system, such as health insurance and tax incentives, perhaps leading to inefficient medical spending. Moreover, the share of medical spending rises with income. 
Missouri could also raise $\$ 155$ million in revenue by imposing a $2 \%$ tax on health insurance policies sold in the state. ${ }^{126}$ Missouri already assesses a $2 \%$ tax on all other insurance premiums sales, only health insurance premiums are exempted. In Missouri, a Massachusetts Model of health reform is likely to result in sales of 461,000 new health insurance policies and increased revenue for private insurers. Thus, tying funding for the plan to health insurance premiums may be appealing. On the other hand, a tax on health insurance premiums taxes only those who purchase health insurance-individuals and small groups. Large employers who self insure would escape this tax and thus fail to contribute an equivalent share to the public costs of the health reform model.

Missouri could also use a tobacco sales tax increase to help fund a Massachusetts Model. Nationally, the average state tax on cigarette sales is just over $\$ 1.00$ a pack. ${ }^{127}$ Missouri's tax of 17 cents per pack is the second lowest in the nation. ${ }^{128}$ Raising Missouri's cigarette tax to 97 cents per pack and increasing the tax on other tobacco products by $20 \%$ would generate $\$ 351$ million a year, enough to fully fund Centers for Disease Control and Prevention ("CDC") recommended smoking cessation programs and raise $\$ 290$ million per year for heath insurance expansion. ${ }^{129}$

Overall, even though the Massachusetts Model health reform would require some form of new taxation, the Model would have a positive effect on Missouri's economy. The plan would bring in over $\$ 1$ billion

126. The Missouri Department of Insurance reports premiums received by all insurers (excluding self-insured plans) is approximately $\$ 6.6$ billion. MCBRIDE ET AL., supra note 38 , at 74 n.73. In addition, it is estimated that insurers would collect another $\$ 1.15$ billion in premiums for the newly insured under a plan of universal coverage. If a $2 \%$ tax on all private insurance premiums (equal to $\$ 7.8$ billion) were to be assessed, preliminary calculations suggest that $\$ 155$ million would be raised. The state presently assesses a Medicaid Managed Care Organization Reimbursement Allowance on net Medicaid revenue of managed care organizations that participate in the Medicaid and SCHIP programs. The federal Deficit Reduction Act of 2005 prohibits this Medicaid-specific tax. Broadening a health insurance tax would net approximately $\$ 100$ million. A health insurance premium tax does not reach those employers who self-insure.

127. Campaign for Tobacco-Free Kids, State Cigarette Excise Tax Rates and Rankings (Oct. 1, 2007), http://tobaccofreekids.org/research/factsheets/pdf/0097.pdf.

128. Id. The state with the lowest state cigarette tax is South Carolina at 7 cents per pack. Id.

129. According to the Committee for a Healthy Future, a $20 \%$ tax on tobacco products would yield $\$ 351$ million per year. After allocating $\$ 61$ million to fully fund CDC recommended smoking education and cessation programs, $\$ 290$ million would be available to fund health insurance coverage. Committee for a Healthy Future, Fact Sheet, http://www.healthymissouri.org/ FactSheet.pdf. Of course, one must acknowledge that Missouri voters have twice failed to pass a ballot resolution to raise the Tobacco Tax. The last proposal, defeated in November 2006, would have earmarked $\$ 102$ million to restore Medicaid cuts, and \$102 million for Medicaid physicians' reimbursement rate increase. This initiative proposed increasing the state tax on cigarettes from $\$ 0.17$ to $\$ 0.97$ per pack. Id. It also proposed a $20 \%$ tax increase on all other tobacco products. Id. 
in new federal Medicaid dollars to the state which would generate additional income, wages, and ultimately increased tax revenue via income tax and sales tax. ${ }^{130}$ Although Missouri would lose individual income tax revenue because more individuals would be able to use pretax dollars to purchase health care, the overall impact on the state's economy would be positive.

\section{CONCLUSION}

The legal frameworks that underlie the Massachusetts Model are relatively straightforward. A Medicaid/SCHIP expansion covers children and the poorest adults, while a Private Insurance Premium Assistance program leverages federal Medicaid matching funds to subsidize insurance for near-poor adults. A Private Insurance Purchasing Pool creates economies of scale to make health insurance more affordable for small businesses and individuals earning over $300 \%$ of the FPL. The employer mandate provides an incentive-albeit a weak one-for employers to continue to contribute toward their employees' health insurance. The individual mandate seeks to bring healthier, less costly individuals into the various health insurance pools.

The costs of implementing the Massachusetts Model in Missouri and other states are substantial, but they are not prohibitive in terms of the state dollars it requires: Creative use of federal Medicaid matching funds pays for one-half to two-thirds the cost of health insurance expansions to cover low income residents. New state revenue is needed, but the amount-while large in dollar figures-is relatively modest in comparison to overall state revenues, and well within the tax capacities of even tax loathe states like Missouri.

This analysis shows that a Massachusetts Model for Missouri is legally and financially possible for Missouri and other states-it can happen. What will happen depends upon the political will of both citizens and elected officials. Others in this symposium have written about the political climate that made reform possible in Massachusetts. We hope that this legal and fiscal analysis will prompt a public conversation in Missouri and elsewhere about what should happen.

130. JoEl FERBER ET AL., ECONOMIC AND HEALTH BENEFITS OF MEDICAID (2004). 